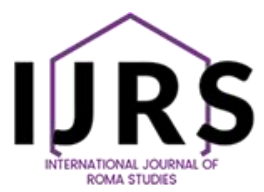

Hipatia Press

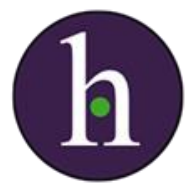

Instructions for authors, subscriptions and further details:

http://ijrs.hipatiapress.com

\title{
Spotlight on voices from the community: COVID-19 impacts on Gypsy, Roma and Traveller communities in England
}

Lucy Hetherington ${ }^{1}$, Jenni Berlin ${ }^{2}$, Mihai Bica ${ }^{3}$ and Violet Cannon ${ }^{4}$

1) Friends, Families and Travellers, United Kingdom

2) Traveller Movement, United Kingdom

3) Roma Support Group, United Kingdom

4) York Traveller's Trust, United Kingdom

Date of publication: September $15^{\text {th }}, 2020$

Edition period: September 2020 - March 2021

To cite this article: Hetherington, L., Berlin, J., Bica, M., \& Cannon, V. (2020). Spotlight on voices from the community: COVID-19 impacts on Gypsy, Roma and Traveller communities in England. International Journal of Roma Studies, 2(2), 87-92. doi: 10.17583/ijrs.2020.6643

To link this article: http://dx.doi.org/10.17583/ijrs.2020.6643

PLEASE SCROLL DOWN FOR ARTICLE

The terms and conditions of use are related to the Open Journal System and to Creative Commons Attribution License (CCAL). 


\section{Spotlight on voices from the community: COVID-19 impacts on Gypsy, Roma and Traveller communities in England}

Lucy Hetherington

Friends, Families and Travellers

Mihai Bica

Roma Support Group
Dr Jenni Berlin

The Traveller Movement

Violet Cannon

York Traveller's Trust

\section{Abstract}

"Spotlight on voices from the community" is a section of the International Journal of Roma Studies (IJRS) where interviews, experiences, initiatives and other news related with the Roma will be collected. This section aims to highlight and share the voices from the community, especially from the Roma People, in order to know more about how to improve the situation of this population and having more information and other points of view about Roma around the world. In this issue organisations and charities based in England reflect on their experiences of "Lockdown" and how they reacted to COVID-19 and the types of programmes or projects they set up to support their local communities.

Keywords: Roma, Gypsy, Traveller, COVID-19, Grassroots

2020 Hipatia Press

ISSN: $2462-425 \mathrm{X}$

DOI: $10.17583 / \mathrm{ijrs} .2020 .6643$
Hipatia Press

www.hipatiapress.com

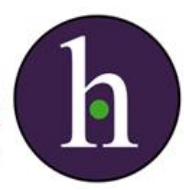




\section{Enfoque en las voces de la}

\section{comunidad: impactos de la \\ COVID-19 en las comunidades}

\section{gitanas, romaníes y nómadas de Inglaterra}

Lucy Hetherington

Friends, Families and Travellers

Mihai Bica

Roma Support Group
Dr Jenni Berlin

The Traveller Movement

Violet Cannon

York Traveller's Trust

\section{Resumen}

"Spotlight on voice from the community" (Enfoque en las voces de la comunidad) es una sección de la revista "International Journal of Roma Studies" (IJRS) donde se recopilarán entrevistas, experiencias, iniciativas y otras noticias relacionadas con la población gitana. Esta sección tiene como objetivo resaltar y compartir las voces de la comunidad, especialmente del pueblo gitano, con el fin de conocer más sobre cómo mejorar la situación de esta población y tener más información y otros puntos de vista sobre los gitanos en el mundo. En este número, las asociaciones y organizaciones benéficas con sede en Inglaterra reflexionan sobre sus experiencias de "bloqueo" y cómo reaccionaron a la COVID-19, así como sobre los tipos de programas o proyectos que establecieron para apoyar a sus comunidades locales.

Palabras clave: Roma, Gitanos, Travellers, COVID-19, Comunidades de base

2020 Hipatia Press

ISSN: 2462-425X

DOI: $10.17583 / \mathrm{ijrs} .2020 .6643$
Hipatia Press

www.hipatiapress.com

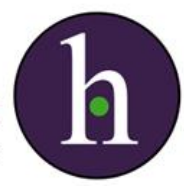




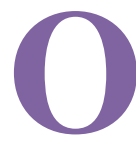

n 16th March 2020, England went into lockdown in the national response to protect individuals and communities from the coronavirus (COVID-19) pandemic. While the public waited for daily updates and adapted their behaviour accordingly, Gypsy, Roma and Traveller civil society needed to quickly adopt new means of service provision and outreach to ensure people from Gypsy, Roma, Traveller and nomadic communities with high needs could still receive advice and support.

This article covers a brief overview of the COVID-19 response from 4 charities supporting people from Gypsy, Roma, Traveller, nomadic and Boater communities.

\section{Friends, Families and Travellers}

Friends, Families and Travellers (FFT) is a leading national charity working on behalf of all Gypsies, Travellers and Roma regardless of ethnicity, culture or background. FFT seek to end racism and discrimination against Gypsies, Travellers and Roma and to protect the right to pursue a nomadic way of life.

Each year, FFT support over 1,000 families with issues ranging from health to homelessness, education to financial inclusion and discrimination to employment. When the country went into lockdown, calls to the national helpline at FFT approximately doubled. There are approximately 3,000 families living roadside in the UK who, at the height of lockdown, had limited or no access to water and sanitation. At this time, there were many questions without answers. With this in mind, FFT created a web-page with a collection of resources for individuals living on sites, unauthorised encampments and living on boats and for local authorities, Traveller site managers and for organisations managing canals and waterways. The advice covered how to address COVID-19 within home settings and guidance on how to self-isolate. The information was made available in audio and video formats to support people with low literacy to access the information.

The national caseworkers at FFT, working with the National Federation of Gypsy Liaison Groups and Community Law Partnership kept in contact to ensure roadside Gypsies and Travellers who had been served eviction notices during this time were receiving adequate advice and guidance to prevent breaches of their rights - this included supporting people to access 


\section{Hetherington et al - COVID-19 impacts on GRT in England}

services/basic amenities such as water and sanitation Over several months, Friends, Families and Travellers and the All Party Parliamentary Group for Gypsies, Travellers and Roma have continually lobbied parliament on the complete lack of guidance on self-isolating for people living on unauthorised encampments, on Traveller sites or on boats and on the absence of guidance for local authorities on the need to stop evictions from roadside camps and to provide camps with basic amenities such as water, sanitation and refuse collection.

At the beginning of lockdown members of FFT's Outreach team in Sussex began routine check-ins with individuals who have physical health issues which made them 'clinically vulnerable' to COVID-19 and to individuals experiencing new or intensified mental health difficulties in response to the pandemic. As part of a larger community network approach, outreach staff were linking clients in with foodbanks, or where necessary delivering food parcels to individuals self-isolating either in bricks and mortar accommodation or living roadside.

Prior to the pandemic, FFT had been running traditional craft and skills workshops. Where it was not possible to make these work in a face-to-face context, skill sharing was encouraged on closed Facebook groups for individuals to share experiments and tutorials. Several members of contributed video tutorials on a range of skills and community members responded with their own. It provided a positive distraction to external events and allowed individuals to practice self-expression.

Understanding that there may be economic barriers preventing people from taking part in this community skill-sharing, craft sets were sent to individuals across the country, including weaving kits, embroidery sets and vouchers and materials for flower arranging supplies: "The kids couldn't wait to start colouring and creating their masterpieces. We've been making things to send to family and friends! It made us really happy - we were so grateful when we couldn't go out." (Service user and parent, 2020)

\section{York Travellers' Trust}

York Travellers' Trust (YTT) is the longest running registered charity in the UK that works solely with Gypsy and Traveller communities. Working primarily in York and the surrounding areas, the organisations' aims are to 
empower Gypsy and Traveller communities and to alleviate social exclusion from mainstream society.

During the lockdown period, face to face outreach services, advisory services and social groups were paused. Concerned about the interruption in contact, and eager to support Gypsies and Travellers in the area to both seek distraction and develop different means of personal interaction, the YTT team used social media to create and share vlogs (video blogs) to keep people engaged. The team delivered craft materials to homes, sites and created a pop-up collection point in the 'community garden' on office property, to encourage clients to participate in creative and distracting activities. These activities included providing a 'How to make a COVID-19 mask' kit.

The YTT office is located in one of York's most deprived areas. The YTT team worked with other local third sector organisations to establish a 'community food stall' which people from the local area could visit to access food items which had been donated from local supermarkets. These food parcels were able to support families in the area who otherwise were struggling to access meals for their families.

When it became unsafe to use cash for shops and services, families in the area reported that they were no longer able to purchase essential items from local services, including diesel for their generators. The family had previously been able to purchase food and goods with cash or post office cards, but were now asked to pay by debit card. As the family didn't have a debit card or a bank account, YTT stepped in to arrange for clients to access prepay debit cards.

\section{Roma Support Group}

Roma Support Group is the first and biggest Roma-led organisation in the UK. Their work with East European Roma refugees and migrants to access welfare, education, housing, health and employment and contributes to the aim of empowering Roma communities through a wide range of advocacy and cultural programmes.

As COVID-19 interrupted face to face and group services, Roma Support Group developed a series of videos providing essential COVID-19 information to Roma communities in multiple languages and dialects. This information included guidance on symptoms, self-isolating, quarantine 


\section{Hetherington et al - COVID-19 impacts on GRT in England}

guidelines and COVID-19 economic support such as the Self Employment Income Support Scheme (SEISS). With children out of school and encouraged to participate in home education, Roma Support Group supported 15 - 20 families' access tutor support and to receive encouragement in education. Only around $20 \%$ of the families engaged with around education had the IT equipment needed to access online learning facilities.

While COVID-19 provided a distraction from Brexit in the UK, EU Citizens were still required to continue as normal with the EU Settlement Scheme (EUSS). Roma Support Group found alternative ways to provide EUSS support, working with a team of 5 advisors who could speak 5 languages. The team organised online EUSS events and developed multiple detailed videos for individuals to access for reference during the pandemic. The organisation found that calls around the EUSS significantly decreased during this time.

The economic impact of COVID-19 put many families in the UK under greater financial stress. Roma Support Group responded to these concerns by providing advice and support through Advice and Advocacy and Financial Inclusion projects. Community members were supported to access support made available from the government, as well as information for dealing with debts, support accessing emergency accommodation and food. Over COVID-19 Roma Support Group worked with over 15 banks and registered as a referral agency enabling them to support service users to access emergency food. For those experiencing mental health issues, Roma Support Group provided ongoing support, as well as arranging monthly online support sessions through the Roma Mental Health Project.

At the beginning of the COVID-19 pandemic, Roma Support Group noticed increased requests for clarity on what support is available and how to access support from the Government, for SEISS and Universal Credit. After this, they experienced a surge in enquiries around accessing emergency food. This was followed by requests around individual debt and housing issues. From August 2020, enquiries are returning to a similar nature as prepandemic, however there has been a surge in calls from people experiencing issues with employers, or regarding seeking employment and from people experiencing street homelessness. 


\section{The Traveller Movement}

The Traveller Movement (TM) is a national charity working with and for Gypsy, Roma and Traveller people in the UK challenging discrimination and promoting inclusion in all aspects of society. Gypsy, Roma and Traveller children face numerous barriers in education (i.e. in exclusions, attainment and bullying) and therefore education is one of TM's main policy, campaign and project areas of work.

As the leading Traveller policy and campaigning organisation in the UK TM has been lobbying different Government Departments for targeted funding and support to address the issues affecting GRT people in the UK during and after the Covid-19 recovery plan. TM has been developing and updating numerous Covid-19 related factsheets and videos to inform UK Gypsies and Travellers about the constantly changing Covid-19 related rules and regulations.

As a reaction to the COVID-19 school closures and parents' having to homeschool their children for several months, TM created an online tutoring project that helps Gypsy, Roma and Traveller children who were having difficulties in accessing or completing the work assigned to them by their schools. From years of experience doing education casework with Gypsy, Roma and Traveller families, TM knew that home schooling would be difficult for many parents because of digital exclusion and/or parent's low literacy levels. Since this initiative was a reaction to COVID-19, TM had no funding for the project and therefore had to rely on volunteer tutors. They have been overwhelmed how many people were willing to volunteer for the project. All tutors in the project are UK DBS (Disclosure and Barring Service) checked, and all online tutoring happens with a parent present. To assure all tutors were understanding of the circumstances some of the families might be facing, TM organised an online induction course for them, and this was made easier by the fact that some of the volunteer tutors are themselves, Gypsy, Roma or Traveller. 'Tutors for GRT' project is inclusive of every Gypsy, Roma 


\section{Hetherington et al-COVID-19 impacts on GRT in England}

or Traveller family regardless of their access to tablets, laptops/computers and printers or the quality of their internet connection. Every tutoring relationship is tailored to the child's needs, using a variety of methods such as delivery of workbooks, fiction books (copies to both tutor and tutee to help with only having a small mobile screen to work with) as well as storytelling and journaling. All first tutoring sessions were done by using WhatsApp video calls. This was the easiest and most inclusive method for all parents and did not require any special equipment, email addresses or logins. Some families 92 Hetherington - COVID-19 impacts on GRT in England have since moved on to Zoom or Google Hangouts, but for many this is not a possibility. The feedback from the families has been extremely positive and TM has seen some real improvement in children's engagement and enthusiasm towards education. The parents and the tutors have reported that they are witnessing the children's confidence increase and the positive aspects that education provides come to live. This is remarkable considering the fact that these are not the typical experiences of Gypsy, Roma or Traveller children within the UK education system. "It's been heartwarming to see my student gain in confidence telling me about how she likes to learn and what she's good at and what she needs me to help her with. Quite different from the shy girl clinging to Mum in our first meeting." (Volunteer tutor, 2020) "It's going great, he totally understands how she is explaining everything and is looking forward to the lesson. I think I might have even been learning by accident." (Parent, 2020)

\section{Summary}

As has been seen by the different sections provided above, grassroots communities and non-Governmental organisations (NGOs) from around England have taken very different approaches to responding to the COVID-19 pandemic. However, each responded and adapted services quickly to engage directly with families and found solutions that worked for that moment in time. 
Lucy Hetherington is the Communications Officer at Friends, Families and Travellers.

Contact address: fft@gypsy-traveller.org

Friends, Families and Travellers, Community Base, 113 Queens Road, Brighton, BN1 3XG

Dr Jenni Berlin is the Partnerships and Community Development Manager at The Traveller Movement

Contact address: The Traveller Movement, Resource for London, 356 Holloway Road, London, N7 6PA

Mihai Bica is the Brexit Information and Campaigning Worker and the Policy and Information Worker at the Roma Support Group

Contact address: info@ romasupportgroup.org.uk

Violet Cannon is the Director at the York Traveller's Trust

Contact address: violet@ytt.org.uk 